\title{
Unprecedented One-Pot Sequence for the Synthesis of Tetrahydroquinoline Alkaloids and Preliminary Evaluation of their Antibacterial Activity
}

\author{
Gaspar Diaz-Muñoz, ${ }^{*, a}$ Izabel L. Miranda, ${ }^{a}$ Suélen K. Sartori, ${ }^{a}$ Gabriel N. S. Dias, ${ }^{b}$ \\ Markus Kohlhoff, ${ }^{c}$ Gislaine A. Purgato ${ }^{d}$ and Marisa A. N. Diaz ${ }^{d}$ \\ ${ }^{a}$ Departamento de Química, Universidade Federal de Minas Gerais, \\ 31270-901 Belo Horizonte-MG, Brazil \\ ${ }^{b}$ Departamento de Aquacultura, Universidade Federal de Minas Gerais, \\ 31270-901 Belo Horizonte-MG, Brazil \\ 'Química de Produtos Naturais Bioativos, Instituto René Rachou, \\ Fundação Oswaldo Cruz (Fiocruz), 30190-002 Belo Horizonte-MG, Brazil \\ ${ }^{d}$ Departamento de Bioquímica e Biologia Molecular, \\ Universidade Federal de Viçosa, 36570-900 Viçosa-MG, Brazil
}

\begin{abstract}
A novel one-pot sequence (in 2 or 3 steps) was developed for the synthesis of the tetrahydroquinoline alkaloids $( \pm)$-galipinine, $( \pm)$-cuspareine, $( \pm)$-galipeine and $( \pm)$-angustureine, and the derivative $( \pm)$-11-methoxy-5,6,6a,7,8,13-hexahydro-13a-aza-benzo[5,6]cyclohepta [1,2- $a]$ naphthalene-12-ol from their respective Wittig adducts in moderate and high yields. The solvolytic $N$-methylation reaction was shown to be catalyzed by $\mathrm{Pt}^{0}$, generated in situ by reduction of $\mathrm{PtO}_{2}$. The evaluation of biofilm inhibition and antibacterial activity of the compounds against Staphylococcus aureus strains isolated from cows with mastitis revealed that the alkaloid derivative is a promising candidate for an antibiotic drug.
\end{abstract}

Keywords: tetrahydroquinoline alkaloids, Wittig reaction, solvolytic $\mathrm{N}$-methylation, antibacterial activity

\section{Introduction}

Tetrahydroquinolines (THQs) are a class of $\mathrm{N}$-heterocyclic natural products that have a wide range of biological activities. ${ }^{1}$ Galipinine, cuspareine, galipeine, and angustureine are 1,2,3,4-tetrahydroquinoline alkaloids representative of this class of compounds (Figure 1). These alkaloids were first isolated from the bark of Galipea officinalis Hancock, a South American tree species popularly known as "angostura"., ${ }^{2,3}$ Notably, these compounds exhibit antimalarial and cytotoxic activities. ${ }^{4}$ Martinellic acid, another exponent of this class of compounds (Figure 1), isolated by Witherup et al. in 1995 from the organic extract of Martinella iquitosensis roots, is known to act as a non-peptide antagonist of the bradykinin $\mathrm{B}_{1}$ and $\mathrm{B}_{2}$ receptors. ${ }^{1,5,6}$

*e-mail: gaspardm@qui.ufmg.br
A wide variety of biological activities has been reported for this class of compounds and their derivatives, including analgesic, ${ }^{7}$ anticonvulsant, ${ }^{8}$ antidepressant, ${ }^{9-11}$ antipsychotic, ${ }^{12}$ antihypertensive, ${ }^{13-16}$ antiallergenic, ${ }^{17}$ antifungal, ${ }^{18}$ antichagasic, ${ }^{19}$ and antiosteoporotic actions. ${ }^{20}$ These compounds show significant immunosuppressant properties and have been investigated for their potential as immunosuppressive drugs..$^{21,22}$ In addition, THQs have been studied for their inhibitory activity toward adenosine monophosphate (AMP)-activated protein kinase, attracting clinical interest for their potential use in the treatment of diabetes. ${ }^{23}$

Because of the utility of 2-substituted THQ compounds in the pharmaceutical industry, these molecules have aroused considerable interest from synthetic organic chemists. Over the years, several synthetic routes have been developed for the preparation of this class of compounds.

Avemaria et al. ${ }^{24}$ for example, described a general method exploring an intramolecular aza-xylylene 
<smiles>CN1c2ccccc2CCC1CCc1ccc2c(c1)OCO2</smiles><smiles>[R]CC1CCCCC1CCc1ccc(OC)c(O)c1</smiles><smiles>CCCCCC1CCc2ccccc2N1C</smiles><smiles>CC(C)=CCNC(=N)NCCCC1Nc2ccc(C(=O)O)cc2C2C1CCN2C(=N)NCC=C(C)C</smiles>

Figure 1. Biologically active compounds containing tetrahydroquinoline scaffolds.

Diels-Alder reaction based on a 1,4-dehydrohalogenation reaction. The method was extended in terms of substrates and leaving groups in order to allow the preparation of THQs in two steps.

Kouznetsov et al. ${ }^{25}$ obtained 1,2,3,4-tetrahydroquinoline compounds using a three-component Diels-Alder imino reaction: trans-anetol, anilines, and benzaldehyde in the presence of $\mathrm{BF}_{3} \cdot \mathrm{Et}_{2} \mathrm{O}$, a simple and efficient one-step method. This protocol is notable for its good yields and mild and cleaner reaction conditions (green chemistry).

Patil et al. ${ }^{26}$ described a method based on a $\mathrm{Pd}^{0}$-catalyzed intramolecular hydroamination for the synthesis of 2-substituted THQs. In this work, the authors synthesized the racemic alkaloids angustureine and galipinine.

Another synthetic approach used for the racemic synthesis of galipinine and angustureine explored a methodology based on an alkylation reaction of 2-cyanotetrahydroquinolinic systems, developed by the Hurvois and co-workers. ${ }^{27}$
An important characteristic observed in the synthesis of almost all of these alkaloids is the use of an $N$-methylation of nor-alkaloids as the last synthetic step. Various conventional protocols for $\mathrm{N}$-methylations are described in the literature in high yields (Scheme 1). ${ }^{28-35}$

As an extension of the pioneering work of Diaz-Muñoz et al. ${ }^{28}$ reporting the Wittig olefination reaction in a phase transfer medium, in the present study, we visualized its synthetic utility for obtaining the 2-alkyl substituted THQ alkaloids galipinine, cuspareine, galipeine, and angustureine in a single step from their respective olefinic intermediates and investigated their antibacterial activity and ability to inhibit biofilm formation.

This synthetic strategy is notable for the unprecedented reaction sequence carried out in one pot (2 or 3 steps), comprising the reduction of exo- and endocyclic double bonds, a debenzylation, and an $N$-methylation step (Scheme 2).

In this reaction, $\mathrm{Pt}^{0}$ catalysis is believed to be involved in

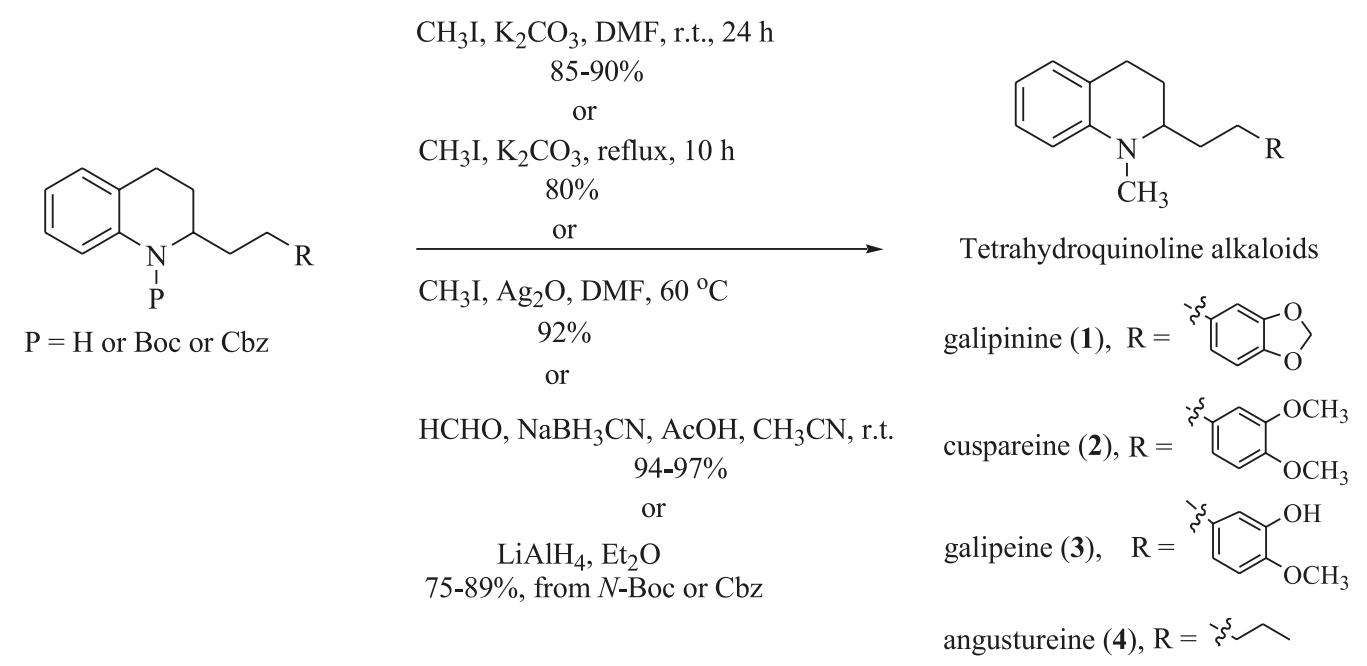

Scheme 1. Conventional $N$-methylation protocols employed in the synthesis of THQ alkaloids. 
<smiles>[R]CCC1CCc2ccccc2N1C</smiles>

$( \pm$ )-galipinine (1), R $=\stackrel{5}{\mathrm{~s}}$

$( \pm$ )-cuspareine (2), $\mathrm{R}=\overbrace{\mathrm{OCH}_{3}}^{\mathrm{OCH}_{3}}$

$\left( \pm\right.$ )-galipeine (3), $\mathrm{R}=\mathrm{OCH}_{3}$

( \pm )-angustureine (4), $R=35$ reduction of endo- and exocyclic double bonds, debenzylation from 9

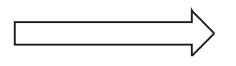

solvolytic $N$-methylation (one pot)<smiles>[R]C=Cc1ccc2ccccc2n1</smiles>

5 or 7 or $\mathbf{9}$ or $\mathbf{1 1}$

Scheme 2. Retrosynthetic analysis of the THQ alkaloids ( \pm )-galipinine, $( \pm)$-cuspareine, $( \pm)$-galipeine, and $( \pm)$-angustureine.

the sequential solvolytic $N$-methylation, in which, the source of the methylating agent is the solvent itself (methanol).

\section{Results and Discussion}

\section{Chemistry}

Based on the retrosynthetic analysis shown in Scheme 2, we consider that the key reaction step of this protocol for alkaloid synthesis is the production of Wittig olefin adducts $\mathbf{5 , 7 , 9}$, and $\mathbf{1 1}$. $^{28}$
After obtaining these olefins and continuing with the synthesis of THQ alkaloids, we observed an anomalous behavior in relation to the method previously used, ${ }^{28}$ probably as a result of a longer reaction time in the first reaction step.

At the step of double bond hydrogenation of olefinic intermediate 5 by treatment with $\mathrm{PtO}_{2}$ in methanol under a hydrogen atmosphere, the reaction was allowed to stir over the weekend, ca. $60 \mathrm{~h}$, a time longer than usually employed $^{28}$ (Scheme 3).

After this period, to our surprise, thin layer chromatography (TLC) analysis of an aliquot of the<smiles>[R]C=Cc1ccc2ccccc2n1</smiles>

5 or $\mathbf{7}$ or $\mathbf{9}$ or $\mathbf{1 1}$
$\mathrm{PtO}_{2}, 1 \mathrm{~atm} \mathrm{H}_{2}, \mathrm{CH}_{3} \mathrm{OH}$

$\underset{\text { r.t., } 8-10 \text { days }}{30-83 \% \text { (2 or } 3 \text { steps }}$

in one pot)<smiles>[R]CCC1CCc2ccccc2N1</smiles>

(5),

(7),

(9),

(11), $\mathrm{R}=\mathrm{s}^{-5} \widehat{\mathrm{C}}$

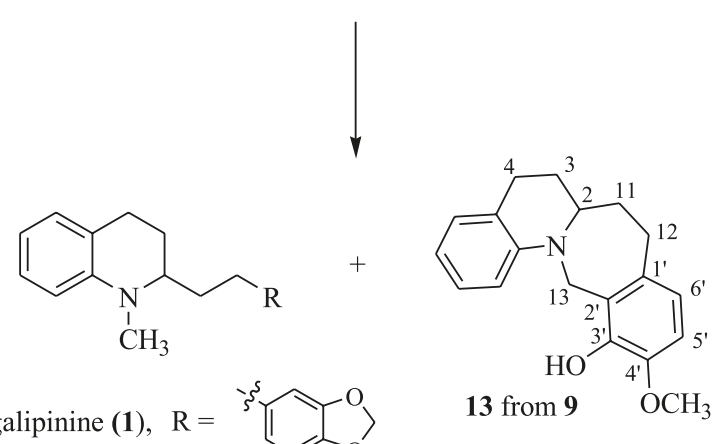

$( \pm)$-cuspareine $(2)$

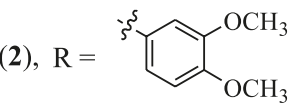

$\left( \pm\right.$ )-galipeine (3), $\mathrm{R}=\mathrm{OCH}_{3}$

$( \pm)$-angustureine (4), $\mathrm{R}=\mathrm{s}^{5} \mathrm{\sim}$ 
reaction allowed us to observe the presence of Wittig adduct 5, nor-galipinine (6), and galipinine (1) in a lower concentration. The direct synthesis of THQ alkaloid $\mathbf{1}$ from olefin $\mathbf{5}$ in one pot had never been verified. In order to investigate this atypical behavior, we left the reaction under stirring for another $12 \mathrm{~h}$. Further monitoring by TLC after this period showed an increase in the concentration of alkaloid $\mathbf{1}$ at the expense of nor-galipinine and a decrease in the concentration of olefin 5 (Scheme 3).

Proceeding with the synthesis for a longer period (96 h), we observed the same behavior as before. There was an increase in the concentration of galipinine (1) and nor-galipinine (6), and total consumption of olefin $\mathbf{5}$ was achieved. Four additional days of continuous stirring under the same conditions were required for complete conversion of nor-galipinine (6) to alkaloid $\mathbf{1}$, according to TLC analysis. Purification of the crude product by column chromatography and analysis of ${ }^{1} \mathrm{H}$ and ${ }^{13} \mathrm{C}$ nuclear magnetic resonance (NMR) spectra allowed the unambiguous identification of $( \pm$ )-galipinine (1), obtained by the one-pot method (two steps) from an olefin adduct (5) in $83 \%$ yield.

As far as we know, this one-pot sequence of simultaneous reduction of endo- and exocyclic double bonds of the quinoline ring and side chain, respectively, in addition to the concomitant solvolytic $\mathrm{N}$-methylation using $\mathrm{PtO}_{2}$, hydrogen atmosphere, and $\mathrm{CH}_{3} \mathrm{OH}$ in the synthesis of $( \pm$ )-galipinine (1) (Scheme 3 ) is a novel result.

This finding was consolidated by the reproduction of the same sequence for the synthesis of THQ alkaloids $\mathbf{2}$, $\mathbf{3}$, and 4 .

The use of the same conditions [catalytic $\mathrm{PtO}_{2} / \mathrm{H}_{2} / \mathrm{CH}_{3} \mathrm{OH}$, 8-10 days (192-240 h)] with the other olefin adducts $(\mathbf{7}, \mathbf{9}$, and 11), without further purification, produced, respectively, $( \pm$ )-cuspareine $(\mathbf{2}),( \pm)$-galipeine $(\mathbf{3})$, and ( \pm )-angustureine (4) in yields of $30-83 \%$ [one pot (2 or 3 steps), Scheme 3].

The synthesis of $( \pm)$-galipeine (3) is also noteworthy because it includes the debenzylation, reduction of double bonds, and $N$-methylation steps in one pot (3 steps from olefin 9). Moreover, synthesis of ( \pm )-galipeine (3) also resulted in the by-product $\mathbf{1 3}$, a novel quinoline alkaloid derivative, in 50\% yield (Scheme 3).
Scheme 4 shows the mechanistic proposal for the formation of by-product 13. The cyclization for the formation of the 7-membered ring (azepine nucleus) must pass through the formation of the iminium ion (13a) generated in situ, which is probably formed with the participation of $\mathrm{Pt}^{0}$ in the catalytic reaction cycle (Scheme 5). Finally, rearomatization of $\mathbf{1 3 b}$ should provide by-product 13 .

The synthesis of cuspareine (2) from olefin adduct $\mathbf{7}$, monitored by TLC, can be visualized in Figure 2. The reaction pattern was identical to that of galipinine (1). After three days ( $72 \mathrm{~h}$ ) of agitation, the almost complete disappearance of spot c, corresponding to olefin 7, was observed as well as the presence of an intense spot b, corresponding to nor-cuspareine (8), and a considerable increase in the intensity of spot a, which corresponds to cuspareine (2). After this period, further 7 days (168 h) of agitation were necessary to complete the synthesis of cuspareine (2) and achieve the total consumption of nor-cuspareine (8), evidenced by the total disappearance of spot $\mathrm{b}$ and the sole presence of an intense spot a.

In the first $24 \mathrm{~h}, 50 \%$ of olefin 7 was consumed, according to TLC observation. However, it took an additional $48 \mathrm{~h}$ to complete the conversion of the olefin into nor-cuspareine (8).

The TLC profile of the reaction (Figure 2) allowed us to observe that the $N$-methylation step is slower than the other steps. However, this apparent disadvantage is fully compensated by the overall yield of the total synthesis of these THQ alkaloids (30-83\%) as well as by the lower costs with reagents, solvents, and materials than required when reactions are carried out step-by-step.

The most intriguing aspect of this unprecedented onepot sequence of reactions is the simultaneous solvolytic $N$-methylation of the in situ generated nor-alkaloids $\mathbf{6}, \mathbf{8}$, $\mathbf{1 0}$, and $\mathbf{1 2}$ for the total synthesis of THQ alkaloids $\mathbf{1}, \mathbf{2}$, $\mathbf{3}$, and 4 (Scheme 3). The use of a system composed of $\mathrm{PtO}_{2} / \mathrm{H}_{2}$ for $N$-alkylation reactions with alcohols had never been reported. ${ }^{36-38}$

A plausible mechanistic proposal for the $N$-methylation reactions is the catalytic cycle presented in Scheme 5. Initially, $\mathrm{PtO}_{2}$ was reduced to $\mathrm{Pt}^{0}$ under hydrogen
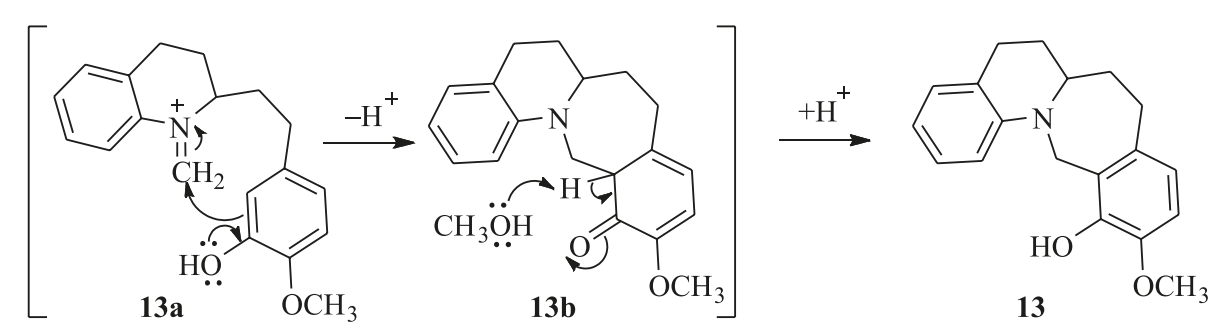

Scheme 4. Mechanistic proposal for the formation of by-product 13. 


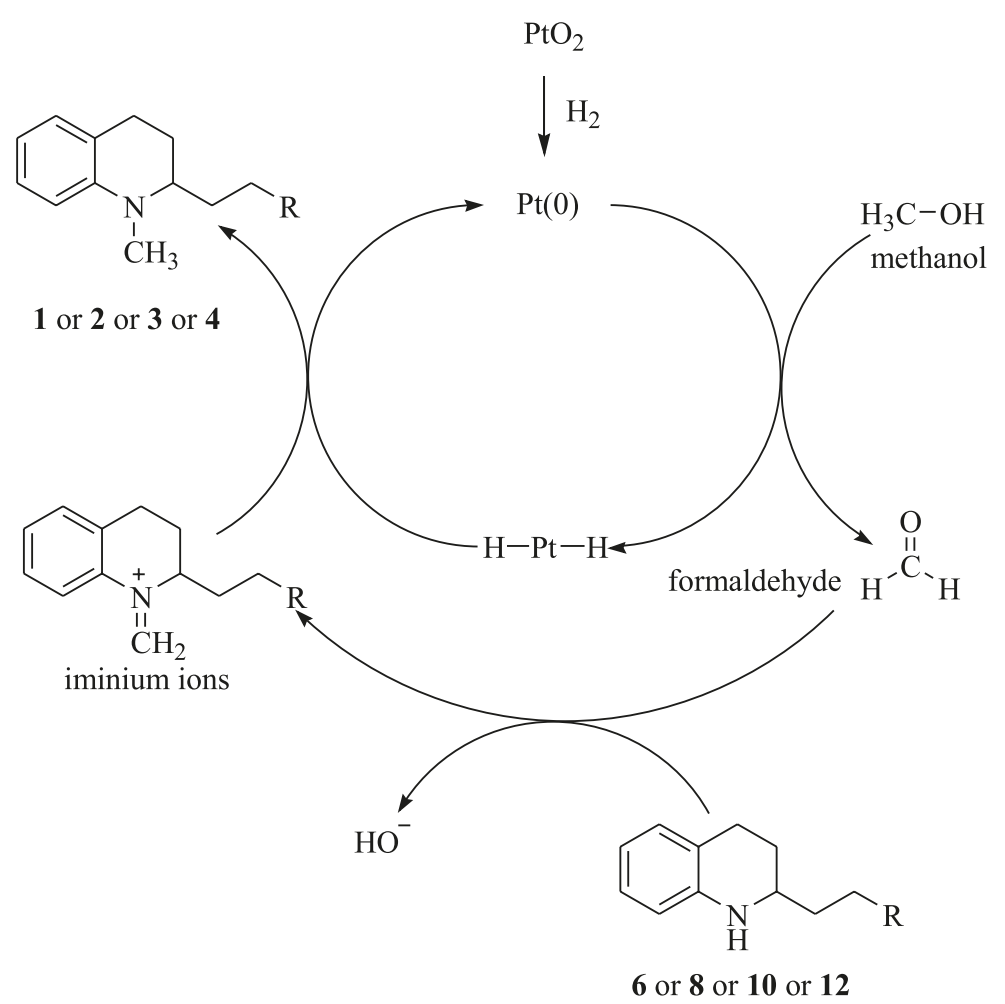

Scheme 5. Catalytic cycle proposal for the simultaneous solvolytic $N$-methylation of the in situ generated nor-alkaloids $\mathbf{6}, \mathbf{8}, \mathbf{1 0}$, and $\mathbf{1 2}$ catalyzed by $\mathrm{PtO}_{2} / \mathrm{H}_{2} / \mathrm{CH}_{3} \mathrm{OH}$.

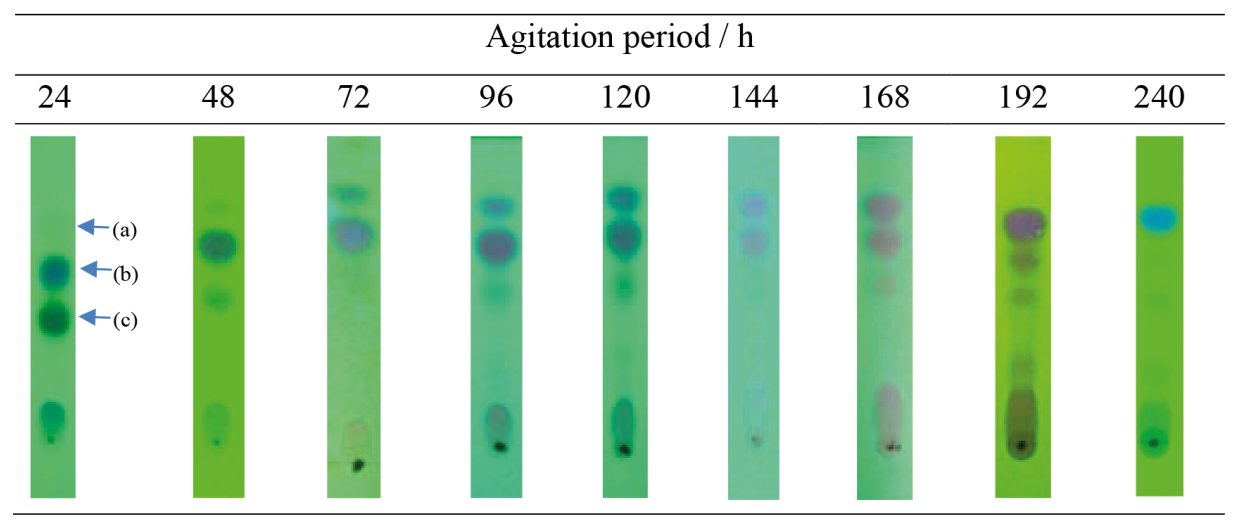

Figure 2. Reaction progression monitored by TLC showing the synthesis of ( \pm )-cuspareine (2) from Wittig adduct 7 in a system composed of $\mathrm{PtO}_{2} / \mathrm{H}_{2} / \mathrm{CH}_{3} \mathrm{OH}$. (a) Cuspareine (2); (b) nor-cuspareine (8); (c) olefin (7). Elution with hexane/EtOAc (8:2).

atmosphere. $\mathrm{Pt}^{0}$ is the reactive metal species in the process. ${ }^{39}$ Methanol was then oxidized by $\mathrm{Pt}^{0}$ to produce formaldehyde and a platinum hydride species $\left(\mathrm{PtH}_{2}\right)$ by abstraction of hydrogen atoms from methanol. The presence of aldehydes in $N$-alkylations of primary amines with alcohols under $\mathrm{Pd} / \mathrm{C}$ catalysis was documented in a study by Liu et $\mathrm{al} .{ }^{38}$ Iminium ions were produced from the condensation of formaldehyde with nor-alkaloids $6,8,10$, and 12. Finally, the desired THQ alkaloids $(\mathbf{1}, \mathbf{2}, \mathbf{3}$, and $\mathbf{4})$ were obtained by reduction of the iminium ions with surface hydrogen atoms from $\mathrm{PtH}_{2}$, promoting the regeneration of the catalyst $\mathrm{Pt}^{0}$.
To understand better the mechanistic proposal for $\mathrm{N}$-methylation, we performed an experiment. For this, we synthesized nor-galipinine (6) from Wittig adduct 5 using the same conditions $\left(\mathrm{PtO}_{2} / \mathrm{H}_{2} / \mathrm{CH}_{3} \mathrm{OH}\right)$ of the one-pot synthesis of $( \pm$ )-galipinine $(\mathbf{1})$. However, this time, the reaction was stopped after $48 \mathrm{~h}$. This change allowed us to obtain, separately, nor-galipinine (6) and $( \pm)$-galipinine (1) after purification of the crude residue by column chromatography. With nor-galipinine (6), we attempted an $\mathrm{N}$-methylation reaction by treatment with $\mathrm{PtO}_{2}$ and $\mathrm{CH}_{3} \mathrm{OH}$ but without the hydrogen atmosphere (Scheme 6). 


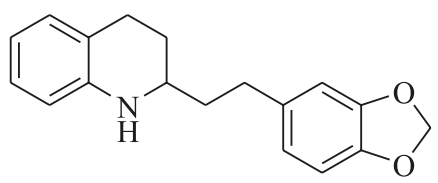

nor-galipinine (6)

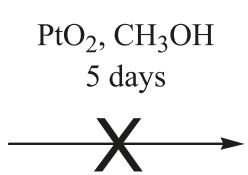

no hydrogen

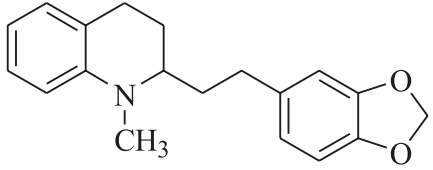

$( \pm)$-galipinine (1) not produced

Scheme 6. Attempted solvolytic $N$-methylation of nor-galipinine (6) catalyzed by $\mathrm{PtO}_{2} / \mathrm{CH}_{3} \mathrm{OH}$ without the presence of molecular hydrogen.

In this last experiment, no formation of the $N$-methylation product was observed after 5 days of continuous stirring, according to TLC analysis. The reaction requires the presence of molecular hydrogen, which allows the in situ formation of metal catalyst $\mathrm{Pt}^{0}$ by reduction of $\mathrm{PtO}_{2}$, thus generating the initiating species of the catalytic cycle (Scheme 5).

Characterization of the THQ alkaloids was performed by infrared (IR), ${ }^{1} \mathrm{H}$ and ${ }^{13} \mathrm{C}$ NMR and mass spectra analysis. These data were in agreement with those described in the literature for these alkaloids obtained from natural sources. ${ }^{2,3}$

Conversely, by-product $\mathbf{1 3}$, obtained in the synthesis of $( \pm$ )-galipeine (3), showed a different pattern for some signals in the ${ }^{1} \mathrm{H}$ and ${ }^{13} \mathrm{C}$ NMR spectra when compared to the signals of $\mathbf{3}$.

In the ${ }^{1} \mathrm{H}$ NMR spectrum, two $\mathrm{AB}$ and $\mathrm{AX}$ isolated spin systems were found, the first being characteristic of aromatic hydrogens and the second of deshielded aliphatic hydrogens, suggesting a structure as that described for compound $\mathbf{1 3}$ in Scheme 3. The ${ }^{1} \mathrm{H}$ NMR spectrum showed two doublets at 6.57 and $6.54 \mathrm{ppm}, J 8.2 \mathrm{~Hz}$, relative to aromatic hydrogens (H-6' and $\mathrm{H}-5$ ') coupling in ortho, and two other doublets relative to deshielded geminated aliphatic hydrogens $\left(\mathrm{H}-13_{\mathrm{a}}\right.$ and $\left.\mathrm{H}-13_{\mathrm{b}}\right)$ at 5.21 and $4.06 \mathrm{ppm}, J 15.8$ and $15.9 \mathrm{~Hz}$, respectively. This type of geminal coupling is only possible in a rigid fused tetracyclic molecule such as $\mathbf{1 3}$, in which there is a lower conformational freedom of the 7-membered ring, leading to a lower interconversion velocity between its conformations, which allows the detection of signals of geminal hydrogens $\left(\mathrm{H}-13_{\mathrm{a}}\right.$ and $\left.\mathrm{H}-13_{\mathrm{b}}\right)$ in different diastereotopic environments. Thus, these hydrogens exhibit different chemical shifts and larger coupling constants $(J 15.8 \mathrm{~Hz})$.

${ }^{13} \mathrm{C}$ NMR spectrum showed signals assignable to 19 carbon atoms. The signal at $46.4 \mathrm{ppm}$ was attributed to a C-13 methylene carbon based on distortionless enhancement by polarization transfer (DEPT) sub-spectrum analysis, compatible with a signal of a $\mathrm{C}-\mathrm{N}$ bond. The heteronuclear multiple bond correlation (HMBC) contour map showed correlations between hydrogens $\mathrm{H}-13_{\mathrm{a}}$ and $\mathrm{H}-13_{\mathrm{b}}$ (5.21 and $4.06 \mathrm{ppm}$ ) and C-2 and C-3' (62.0 and
$143.1 \mathrm{ppm}$, respectively) (Figure 3), thereby confirming the structure of compound $\mathbf{1 3}$.

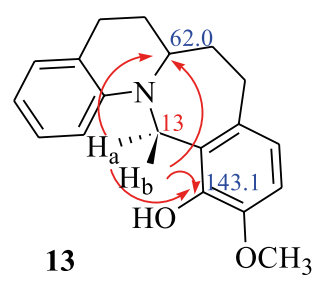

Figure 3. Key HMBC correlations of compound 13.

\section{Biological assays}

Having synthesized the THQ alkaloids ( \pm )-galipinine, $( \pm)$-cuspareine, $( \pm)$-galipeine and $( \pm)$-angustureine, and the derivative $( \pm)$-11-methoxy-5,6,6a, 7,8,13-hexahydro13a-aza-benzo[5,6]cyclohepta[1,2-a]naphthalene-12-ol and encouraged by the interest in the bioprospecting of novel drugs, antibacterial assays were performed to evaluate the action of the compounds against Staphylococcus aureus strains isolated from cows with bovine mastitis. The results revealed that only the derivative compound $\mathbf{1 3}$ had strong antibacterial activity; the THQ alkaloids did not present any significant activity. In view of this, the investigation was continued only with compound $\mathbf{1 3}$. The minimum inhibitory concentration (MIC) of the compound against 15 strains of $S$. aureus bacteria was determined, and the antibiotic ciclopirox olamine was used as a positive control (Table 1).

Analysis of the results of antibacterial activity of compound 13 against 15 S. aureus strains, shown in Table 1, revealed some interesting information. The compound showed MIC values (0.031-0.062 $\left.\mathrm{mg} \mathrm{mL}^{-1}\right)$ equal to or lower than those of the control drug (ciclopirox olamine) for eight strains of S. aureus $(8907,8908,8923,8925,8958$, $8959,9000$, and 9005$)$, suggesting that it is a biologically promising compound.

Encouraged by the excellent MIC results, we decided to test the ability of compound $\mathbf{1 3}$ to inhibit preformed biofilms of the strains against which it was most active, in addition to strain 8955 , which showed a reasonable MIC of $0.125 \mathrm{mg} \mathrm{mL}^{-1}$ (Table 1).

The best results of biofilm inhibition of compound $\mathbf{1 3}$ were obtained against strains $8907,8908,8955,8959$, and 
Table 1. Minimum inhibitory concentration (MIC) of compound $\mathbf{1 3}$ against Staphylococcus aureus isolates

\begin{tabular}{lcc}
\hline S. aureus strain & $\begin{array}{c}\text { MIC of compound 13 / } \\
\left(\mathrm{mg} \mathrm{mL}^{-1}\right)\end{array}$ & $\begin{array}{c}\text { MIC of antibiotic } \\
\left(\mathrm{mg} \mathrm{mL}^{-1}\right)\end{array}$ \\
\hline 3008 & 0.500 & 0.05 \\
3828 & 0.250 & 0.05 \\
3917 & 1.000 & 0.03 \\
4157 & 2.000 & 0.03 \\
4182 & 0.250 & 0.05 \\
8907 & 0.062 & 0.03 \\
8908 & 0.031 & 0.04 \\
8923 & 0.031 & 0.04 \\
8925 & 0.031 & 0.05 \\
8955 & 0.125 & 0.05 \\
8958 & 0.031 & 0.03 \\
8959 & 0.031 & 0.03 \\
8996 & 0.500 & 0.05 \\
9000 & 0.031 & 0.05 \\
9005 & 0.062 & 0.05 \\
\hline
\end{tabular}

${ }^{\mathrm{a} C i c l o p i r o x}$ olamine.

9005. Inhibition ranged from 94 to $100 \%$ at $2 \mathrm{MIC}$ and from 92 to $100 \%$ at 1 MIC for the same strains except 8959 (Table 2). These promising results show that compound $\mathbf{1 3}$ inhibited biofilm formation by some $S$. aureus strains and achieved, in some cases, similar results to those obtained with the control drug, suggesting its great potential as a drug candidate.

\section{Conclusions}

A novel one-pot sequence (in 2 or 3 steps) of reduction of endo- and exocyclic double bonds, debenzylation, and solvolytic $N$-methylation catalyzed by $\mathrm{PtO}_{2} / \mathrm{H}_{2} / \mathrm{CH}_{3} \mathrm{OH}$ was developed as a protocol for the synthesis of 2-alkyltetrahydroquinoline alkaloids from Wittig olefin adducts in moderate to high yields (30-83\%).
The MIC results of compound 13 (0.031-0.062 $\left.\mathrm{mg} \mathrm{mL}^{-1}\right)$ against some $S$. aureus strains were equal to or better than those of the control drug. The biofilm inhibition assay revealed that compound $\mathbf{1 3}$ was able to inhibit up to $100 \%$ of biofilm formation of some $S$. aureus strains. These results lead us to believe that compound $\mathbf{1 3}$ has great potential as an antimicrobial agent. ${ }^{40}$

\section{Experimental}

\section{General procedures}

${ }^{1} \mathrm{H}$ and ${ }^{13} \mathrm{C}$ NMR spectra were recorded on a Bruker Avance spectrometer at 400 and $100 \mathrm{MHz}$, respectively. The liquid chromatography tandem mass spectrometry (LC-MS/MS) analyses were performed on a Shimadzu Nexera UHPLC system coupled to a Bruker maXis ETD electrospray ionization (ESI)-quadrupole time-of-flight (QTOF) high-resolution mass spectrometer (HRMS). IR spectra were recorded on a Fourier transform IR (FTIR) spectrometer with a diamond attenuated total reflectance (ATR) accessory as a thin film. Melting points were measured in open capillary tubes using an Electrothermal IA 9100 digital melting point apparatus and were not corrected. Purification by column chromatography was performed on silica gel (70-230 or 230-400 mesh). TLC visualization was achieved by spraying with 5\% ethanolic phosphomolybdic acid and subsequent heating. Tetrahydrofuran (THF) was distilled from sodium metal and benzophenone ketyl under nitrogen. Dimethylformamide (DMF) and dichloromethane were distilled from $\mathrm{CaH}_{2}$. Acetonitrile was dried over $4 \AA$ molecular sieves $(24 \mathrm{~h})$ and distilled from $1 \%(\mathrm{~m} / \mathrm{v}) \mathrm{P}_{2} \mathrm{O}_{5}$. All chemicals were used as received unless otherwise stated.

\section{Synthesis}

\section{$( \pm)$-Galipinine (1)}

The crude olefin $\mathbf{5}$, obtained following the protocol established by Diaz-Muñoz et al. ${ }^{28}$ was used without

Table 2. Effect of compound $\mathbf{1 3}$ on biofilm formation by Staphylococcus aureus strains

\begin{tabular}{lccccccccc}
\hline $\begin{array}{l}\text { Concentration / } \\
\left(\mathrm{mg} \mathrm{mL}^{-1}\right)\end{array}$ & 8907 & 8908 & 8923 & 8925 & 8955 & 9858 & 8959 & 9000 & 9005 \\
\cline { 2 - 10 } & 97.56 & 96.82 & 54.75 & 69.26 & 94.11 & 63.54 & 100 & 54.29 & 100 \\
$1 \mathrm{MIC}$ & 97.27 & 92.62 & 2.19 & 44.17 & 91.50 & 42.54 & 59.37 & 40.61 & 100 \\
$0.5 \mathrm{MIC}$ & 96.16 & 12.33 & 1.85 & 28.56 & 87.60 & 40.06 & 49.18 & 34.72 & 57.21 \\
$0.25 \mathrm{MIC}^{\mathrm{MIC}}$ & 71.22 & 12.16 & 1.27 & 19.72 & 81.27 & 35.66 & 46.82 & 34.27 & 5.51 \\
Control $^{\mathrm{a}}$ & 98.01 & 100 & 100 & 100 & 98.18 & 100 & 100 & 100 & 100 \\
\hline
\end{tabular}

aCiclopirox olamine. MIC: minimum inhibitory concentration. 
prior purification, dissolved in anhydrous methanol (10.5 mL), treated with $\mathrm{PtO}_{2}(53.4 \mathrm{mg}, 0.235 \mathrm{mmol})$, and stirred at room temperature for 8 days under a balloon atmosphere of hydrogen. The reaction mixture was filtered with dichloromethane through celite, dried over anhydrous sodium sulfate, and concentrated under reduced pressure. The crude residue was purified by column chromatography by using hexane/EtOAc $98: 2$ as eluent to afford ( \pm )-galipinine (1) as a yellowish oil in $83 \%$ overall yield (three steps); Rf 0.41 (90:10 hexane/EtOAc); IR (film) $\mathrm{V} / \mathrm{cm}^{-1}$ 3018, 2931, 2889, 1601, 1498, 1487, 1440, 1241, 1036, 925, 804, 742; ${ }^{1} \mathrm{H}$ NMR (400 MHz, $\left.\mathrm{CDCl}_{3}\right) \delta 7.06$ (t, $1 \mathrm{H}, J 7.0 \mathrm{~Hz}, \mathrm{Ar}-\mathrm{H}), 6.96(\mathrm{~d}, 1 \mathrm{H}, J 6.5 \mathrm{~Hz}, \mathrm{Ar}-\mathrm{H})$, 6.71-6.67 (m, 2H, Ar-H), 6.62-6.57 (m, 2H, Ar-H), 6.51 (d, $1 \mathrm{H}, J 7.9 \mathrm{~Hz}, \mathrm{Ar}-\mathrm{H}), 5.89$ (s, $\left.2 \mathrm{H}, \mathrm{OCH}_{2} \mathrm{O}\right), 3.28-3.22$ $(\mathrm{m}, 1 \mathrm{H}, \mathrm{C}-\mathrm{H}), 2.89\left(\mathrm{~s}, 3 \mathrm{H}, \mathrm{NCH}_{3}\right), 2.82-2.78(\mathrm{~m}, 1 \mathrm{H}$, $\mathrm{C}-\mathrm{H}), 2.69-2.58(\mathrm{~m}, 2 \mathrm{H}, 2 \mathrm{C}-\mathrm{H}), 2.52-2.45(\mathrm{~m}, 1 \mathrm{H}, \mathrm{C}-\mathrm{H})$, 1.98-1.82 (m, 3H, 3C-H), 1.74-1.63 (m, 1H, C-H); ${ }^{13} \mathrm{C} \mathrm{NMR}\left(100 \mathrm{MHz}, \mathrm{CDCl}_{3}\right) \delta 147.6,145.6,145.3,135.8$, 128.6, 127.1, 121.7, 120.9, 115.4, 110.6, 108.7, 108.1, 100.7, 58.2, 38.0, 33.2, 32.0, 24.4, 23.6; HRMS (ESI-TOF) calcd. for $\mathrm{C}_{19} \mathrm{H}_{21} \mathrm{NO}_{2}[\mathrm{M}+\mathrm{H}]^{+}:$296.1651; found: 296.1650 .

2-(2-Benzo[1,3]dioxol-5-yl-ethyl)-1,2,3,4-tetrahydroquinoline (6)

Nor-galipinine (6) was prepared similarly to galipinine (1), but remained under continuous agitation for only 2 days. The residue was purified by silica gel column chromatography by eluting with hexane/EtOAc (9.3:0.7) to afford an unconsumed amount of Wittig adduct 5 (not characterized) and nor-galipinine (6) as a pale yellow solid; Rf 0.75 (hexane/EtOAc 7:3); mp 67.5-68.3 ${ }^{\circ} \mathrm{C}$; IR (film) $\mathrm{v} / \mathrm{cm}^{-1} 3389,3009,2968,2916,2853,1602,1584,1487$, 1440, 1247, 1187, 1032, 924, 803, 751; ${ }^{1} \mathrm{H}$ NMR $(400 \mathrm{MHz}$, $\left.\mathrm{CDCl}_{3}\right) \delta$ 6.96-6.92 (m, 2H, 2Ar-H), $6.72(\mathrm{~d}, 1 \mathrm{H}, J 7.8 \mathrm{~Hz}$, Ar-H), 6.68 (s, 1H, Ar-H), 6.64 (d, 1H, J 8.0 Hz, Ar-H), 6.59 (t, $1 \mathrm{H}, J 7.5 \mathrm{~Hz}, \mathrm{Ar}-\mathrm{H}), 6.44$ (d, 1H, J 7.8 Hz, Ar-H), $5.90\left(\mathrm{~s}, 2 \mathrm{H}, \mathrm{OCH}_{2} \mathrm{O}\right), 3.72$ (sh, 1H, N-H), 3.29-3.23 (m, $1 \mathrm{H}, \mathrm{C}-\mathrm{H}), 2.83-2.68(\mathrm{~m}, 2 \mathrm{H}, 2 \mathrm{C}-\mathrm{H}), 2.66-2.62(\mathrm{~m}, 2 \mathrm{H}$, 2C-H), 2.00-1.93 (m, 1H, C-H), 1.79-1.74 (m, 2H, 2C-H), 1.69-1.60 (m, $1 \mathrm{H}, \mathrm{C}-\mathrm{H}) ;{ }^{13} \mathrm{C}$ NMR (100 MHz, $\mathrm{CDCl}_{3}$ ) $\delta$ 147.9, 145.9, 144.7, 135.8, 129.4, 126.9, 121.5, 121.2, 117.2, 114.3, 108.9, 108.4, 101.0, 51.2, 38.6, 32.1, 28.2, 26.4; HRMS (ESI-TOF) calcd. for $\mathrm{C}_{18} \mathrm{H}_{19} \mathrm{NO}_{2}[\mathrm{M}+\mathrm{H}]^{+}$: 282.1494; found: 282.1493 .

\section{$( \pm)$-Cuspareine (2)}

Cuspareine (2) was prepared similarly to galipinine (1), except that the mixture was kept under continuous agitation for 10 days. The crude residue was purified by silica gel column chromatography by eluting with hexane/EtOAc
(9.5:0.5) to afford ( \pm )-cuspareine (2) as a yellowish oil in $82 \%$ overall yield; Rf 0.79 (hexane/EtOAc 8:2); IR (film) $\mathrm{v} / \mathrm{cm}^{-1} 2932,2833,1601,1518,1498,1259,1233,1139$, 1027, 803, 742; ${ }^{1} \mathrm{H}$ NMR (400 MHz, $\left.\mathrm{CDCl}_{3}\right) \delta 7.07(\mathrm{t}, 1 \mathrm{H}$, $J 7.0 \mathrm{~Hz}, \mathrm{Ar}-\mathrm{H}), 6.96$ (d, $1 \mathrm{H}, J 7.2 \mathrm{~Hz}, \mathrm{Ar}-\mathrm{H}), 6.77$ (d, 1H, $J 7.9 \mathrm{~Hz}, \mathrm{Ar}-\mathrm{H}), 6.72(\mathrm{~s}, 1 \mathrm{H}, \mathrm{Ar}-\mathrm{H}), 6.70$ (s, 1H, Ar-H), 6.58 (t, $1 \mathrm{H}, J 7.3 \mathrm{~Hz}, \mathrm{Ar}-\mathrm{H}), 6.52$ (d, 1H, J $8.2 \mathrm{~Hz}, \mathrm{Ar}-\mathrm{H})$, $3.85\left(\mathrm{~s}, 3 \mathrm{H}, \mathrm{OCH}_{3}\right), 3.84\left(\mathrm{~s}, 3 \mathrm{H}, \mathrm{OCH}_{3}\right), 3.29-3.25(\mathrm{~m}, 1 \mathrm{H}$, $\mathrm{C}-\mathrm{H}), 2.90$ (s, $3 \mathrm{H}, \mathrm{NCH}_{3}$ ), 2.88-2.79 (m, 1H, C-H), 2.702.62 (m, 2H, 2C-H), 2.56-2.48 (m, 1H, C-H), 1.95-1.86 (m, $3 \mathrm{H}, 3 \mathrm{C}-\mathrm{H}), 1.77-1.67$ (m, 1H, C-H); ${ }^{13} \mathrm{C}$ NMR $(100 \mathrm{MHz}$, $\left.\mathrm{CDCl}_{3}\right) \delta 148.9,147.2,145.3,134.6,128.6,127.0,121.7$, 120.0, 115.4, 111.7, 111.4, 110.6, 58.3, 55.9, 55.8, 38.0, 33.0, 31.9, 24.4, 23.5; HRMS (ESI-TOF) calcd. for $\mathrm{C}_{20} \mathrm{H}_{25} \mathrm{NO}_{2}[\mathrm{M}+\mathrm{H}]^{+}:$312.1964; found: 312.1957 .

( \pm )-Galipeine (3) and ( \pm )-11-methoxy-5,6,6a, 7,8,13-hexahydro-13a-aza-benzo[5,6]cyclohepta[1,2-a]naphthalene12-ol (13)

Galipeine (3) was prepared similarly to galipinine (1), under stirring at room temperature for 8 days. The crude residue was purified by silica gel column chromatography by eluting with hexane/EtOAc (9.5:0.5) to afford ( \pm )-galipeine (3) as a light yellowish oil in 30\% yield, Rf 0.59 (hexane/EtOAc 8:2), and 11-methoxy-5,6,6a,7,8,13-hexahydro-13a-azabenzo[5,6]cyclohepta[1,2-a]naphthalene-12-ol (13) in 50\% yield, Rf 0.68 (hexane/EtOAc 8:2).

\section{Data for ( \pm )-galipeine (3)}

IR (film) v / $\mathrm{cm}^{-1} 3516,2922,2852,1595,1502,1456$, 1265, 1207, 1019, 800, 747; ${ }^{1} \mathrm{H}$ NMR (400 MHz, $\left.\mathrm{CDCl}_{3}\right)$ $\delta 7.06$ (t, 1H, J 7.7 Hz, Ar-H), 6.96 (d, 1H, J 7.2 Hz, Ar-H), 6.77-6.75 (m, 1H, Ar-H), 6.74 (s, 1H, Ar-H), 6.64 (dd, 1H, $J$ 8.2, $1.4 \mathrm{~Hz}, \mathrm{Ar}-\mathrm{H}), 6.57$ (t, $1 \mathrm{H}, J 7.3 \mathrm{~Hz}, \mathrm{Ar}-\mathrm{H}), 6.51$ (d, 1H, J $8.2 \mathrm{~Hz}, \mathrm{Ar}-\mathrm{H}), 5.57$ (sl, 1H, O-H), 3.84 (s, 3H, $\left.\mathrm{OCH}_{3}\right), 3.25$ (sext, $\left.1 \mathrm{H}, J 4.4 \mathrm{~Hz}, \mathrm{C}-\mathrm{H}\right), 2.89$ (s, 3H, $\mathrm{NCH}_{3}$ ), 2.87-2.78 (m, 1H, C-H), 2.67 (dt, $1 \mathrm{H}, J 16.4,4.2 \mathrm{~Hz}, \mathrm{C}-\mathrm{H})$, 2.62-2.57 (m, 1H, C-H), 2.51-2.44 (m, 1H, C-H), 1.95$1.84(\mathrm{~m}, 3 \mathrm{H}, 3 \mathrm{C}-\mathrm{H}), 1.74-1.65(\mathrm{~m}, 1 \mathrm{H}, \mathrm{C}-\mathrm{H}) ;{ }^{13} \mathrm{C}$ NMR $\left(100 \mathrm{MHz}, \mathrm{CDCl}_{3}\right) \delta 145.7,145.5,144.9,135.5,128.8$, 127.3, 122.0, 119.7, 115.6, 114.7, 110.9, 110.8, 58.4, 56.2, 38.2, 33.1, 31.8, 24.6, 23.8; HRMS (ESI-TOF) calcd. for $\mathrm{C}_{19} \mathrm{H}_{23} \mathrm{NO}_{2}[\mathrm{M}+\mathrm{H}]^{+}:$298.1807; found: 298.1809 .

Data for ( \pm )-11-methoxy-5,6,6a,7,8,13-hexahydro-13a-azabenzo[5,6]cyclohepta[1,2-a]naphthalene-12-ol (13)

IR (film) $v / \mathrm{cm}^{-1} 3443,3019,2937,2836,1602,1492$, $1263,1064,742 ;{ }^{1} \mathrm{H}$ NMR $\left(400 \mathrm{MHz}, \mathrm{CDCl}_{3}\right) \delta 7.08(\mathrm{~d}$, 1H, $J 8.3 \mathrm{~Hz}, \mathrm{Ar}-\mathrm{H}$ ), 6.99 (t, 1H, J 7.6 Hz, Ar-H), 6.88 $(\mathrm{d}, 1 \mathrm{H}, J 7.2 \mathrm{~Hz}, \mathrm{Ar}-\mathrm{H}), 6.57(\mathrm{~d}, 1 \mathrm{H}, J 8.2 \mathrm{~Hz}, \mathrm{Ar}-\mathrm{H})$, 6.54 (d, 1H, J 8.2 Hz, Ar-H), 6.50 (t, 1H, J 7.2 Hz, Ar-H), 
$5.94(\mathrm{sl}, 1 \mathrm{H}, \mathrm{O}-\mathrm{H}), 5.21\left(\mathrm{~d}, 1 \mathrm{H}, J 15.8 \mathrm{~Hz}, \mathrm{C}-\mathrm{H}_{\alpha}\right), 4.06$ (d, $1 \mathrm{H}, J 15.9 \mathrm{~Hz}, \mathrm{C}-\mathrm{H}_{\beta}$ ), 3.80 (s, $3 \mathrm{H}, \mathrm{OCH}_{3}$ ), 3.72-3.67 (m, 1H, C-H), 3.08-3.01 (m, 1H, C-H), 2.85-2.72 (m, $2 \mathrm{H}$, 2C-H), 2.64 (dt, 1H, J 13.8, 4.2 Hz, C-H), 2.09-2.01 (m, $1 \mathrm{H}, \mathrm{C}-\mathrm{H}), 1.85-1.73(\mathrm{~m}, 3 \mathrm{H}, 3 \mathrm{C}-\mathrm{H}) ;{ }^{13} \mathrm{C}$ NMR $(100 \mathrm{MHz}$, $\left.\mathrm{CDCl}_{3}\right) \delta 144.6,143.9,143.1,135.8,128.7,127.1,125.0$, 121.3, 120.1, 115.4, 111.9, 108.4, 62.0, 56.0, 46.4, 35.4, 33.0, 28.0, 24.4; HRMS (ESI-TOF) calcd. for $\mathrm{C}_{19} \mathrm{H}_{22} \mathrm{NO}_{2}$ $[\mathrm{M}+\mathrm{H}]^{+}:$296.1645; found: 296.1645 .

\section{( \pm )-Angustureine (4)}

Angustureine (4) was prepared similarly to galipinine (1) from olefin (11), but under continuous agitation for 9 days. The crude residue was purified by silica gel column chromatography by eluting with hexane/EtOAc (9.9:0.1) to afford ( \pm )-angustureine $(4)$ as a translucent oil in $85 \%$ yield; Rf 0.85 (hexane/EtOAc 9.5:0.5); IR (film) v / $\mathrm{cm}^{-1} 3064$, 2926, 2856, 1602, 1499, 1334, 1214, 741, 717; ${ }^{1} \mathrm{H}$ NMR $\left(400 \mathrm{MHz}, \mathrm{CDCl}_{3}\right) \delta 7.08(\mathrm{t}, 1 \mathrm{H}, J 7.7 \mathrm{~Hz}, \mathrm{Ar}-\mathrm{H}), 6.95(\mathrm{~d}$, $1 \mathrm{H}, J 7.3 \mathrm{~Hz}, \mathrm{Ar}-\mathrm{H}), 6.56(\mathrm{td}, 1 \mathrm{H}, J 7.3,0.7 \mathrm{~Hz}, \mathrm{Ar}-\mathrm{H})$, $6.51(\mathrm{~d}, 1 \mathrm{H}, J 8.2 \mathrm{~Hz}, \mathrm{Ar}-\mathrm{H}), 3.22$ (sext, $1 \mathrm{H}, J 4.4 \mathrm{~Hz}$, $\mathrm{C}-\mathrm{H}), 2.91\left(\mathrm{~s}, 3 \mathrm{H}, \mathrm{NCH}_{3}\right), 2.83-2.75(\mathrm{~m}, 1 \mathrm{H}, \mathrm{C}-\mathrm{H}), 2.64$ (td, 1H, J 16.2, 4.2 Hz, C-H), 1.90-1.85 (m, 2H, 2C-H), $1.62-1.54(\mathrm{~m}, 1 \mathrm{H}, \mathrm{C}-\mathrm{H}), 1.41-1.25(\mathrm{~m}, 7 \mathrm{H}, 7 \mathrm{C}-\mathrm{H}), 0.89(\mathrm{t}$, $3 \mathrm{H}, J 6.8 \mathrm{~Hz}, 3 \mathrm{C}-\mathrm{H}) ;{ }^{13} \mathrm{C} \mathrm{NMR}\left(100 \mathrm{MHz}, \mathrm{CDCl}_{3}\right) \delta 145.6$, 128.8, 127.2, 122.1, 115.4, 110.6, 59.2, 38.1, 32.2, 31.4, 26.0, 24.7, 23.8, 22.9, 14.2; HRMS (ESI-TOF) calcd. for $\mathrm{C}_{15} \mathrm{H}_{23} \mathrm{~N}[\mathrm{M}+\mathrm{H}]^{+}:$218.1909; found: 218.1900 .

\section{Biological activities}

Determination of the MIC of 11-methoxy-5,6,6a,7,8,13-hexahydro-13a-aza-benzo[5,6]cyclohepta[1,2-a]naphthalene12-ol (13)

Staphylococcus aureus strains 3828, 4157, 4182, 3917, 3008, 8923, 8925, 8959, 8996, 8955, 8958, 8907, 8908, 9000 , and 9005, isolated from animals with bovine mastitis, were kindly provided by Empresa Brasileira de Pesquisa Agropecuária (Embrapa)/Centro Nacional de Pesquisa de Gado de Leite (CNPGL), Juiz de Fora-MG, Brazil. The MIC assay was performed using the microdilution method described in Clinical and Laboratory Standards Institute (CLSI) guidelines ${ }^{41}$ with modifications. First, a serial dilution of the compound was performed, in which $100 \mu \mathrm{L}$ of the compound at a concentration of $4 \mathrm{mg} \mathrm{mL}^{-1}$ were added to $100 \mu \mathrm{L}$ of brain heart infusion (BHI) culture medium in a well plate; $100 \mu \mathrm{L}$ of this solution were drawn and homogenized with $100 \mu \mathrm{L}$ of culture medium in the next well, and so on, thereby obtaining a series of concentrations ranging from 2.0 to $0.031 \mathrm{mg} \mathrm{mL}^{-1}$. Then, $100 \mu \mathrm{L}$ of bacterial suspension adjusted to
$10^{6}$ colony-forming units $(\mathrm{CFU}) \mathrm{mL}^{-1}$ were added to each well. As a negative control, the solvent dimethyl sulfoxide (DMSO) was used at a final concentration of $5 \%$ in the well, and, as a positive control, $10 \mu \mathrm{L}$ of the antibiotic ciclopirox olamine were added to the well. The microplate was maintained at $37{ }^{\circ} \mathrm{C}$ for $24 \mathrm{~h}$. After incubation, $20 \mu \mathrm{L}$ of resazurin $(0.01 \%)$ were added. Tests were performed in duplicate. The microplates were incubated for an additional $2 \mathrm{~h}$ at $37^{\circ} \mathrm{C}$. MIC determination was qualitative and visual, as wells with viable bacteria are of a pinkish color and wells with non-viable bacteria are blue. MIC was determined as the concentration of compound in the first well of the series that was stained blue.

Effect of 11-methoxy-5,6,6a,7,8,13-hexahydro-13a-azabenzo[5,6]cyclohepta[1,2-a]naphthalene-12-ol (13) on preformed biofilms

The effect of compound $\mathbf{1 3}$ on preformed biofilms was determined according to the method described by Klein et al. ${ }^{42}$ with some modifications and using $S$. aureus strains 8925, 8923, 8955, 8958, 8907, 8908, 9000, and 9005. In 96-well microplates, $100 \mu \mathrm{L}$ of BHI culture medium supplemented with $0.25 \%$ glucose (BHIg) and $100 \mu \mathrm{L}$ of bacterial suspension adjusted to $0.5 \mathrm{McFarland}$ standard were added. The microplates were incubated at $37^{\circ} \mathrm{C}$ for $24 \mathrm{~h}$. Next, absorbances were read at $600 \mathrm{~nm}$ on an enzyme-linked immunosorbent assay (ELISA) reader to confirm the presence of bacterial growth in the culture medium. The supernatants were carefully removed from the wells, and $200 \mu \mathrm{L}$ of BHI were added along with the compound in the following concentrations: $2 \mathrm{MIC}, 1 \mathrm{MIC}$, $0.5 \mathrm{MIC}$, and 0.25 MIC. The microplates were incubated for $6 \mathrm{~h}$, the supernatants were discarded, and the wells were washed twice with $200 \mu \mathrm{L}$ of $1 \times$ phosphate-buffered saline (PBS) buffer, pH 7.4. Then, wells were stained with $200 \mu \mathrm{L}$ of $0.1 \%$ crystal violet $(\mathrm{CV})$ for $30 \mathrm{~min}$. Excess $\mathrm{CV}$ was removed by washing the wells three times with $200 \mu \mathrm{L}$ of distilled water. Finally, $150 \mu \mathrm{L}$ of $95 \%$ ethanol were added to the wells and, after $45 \mathrm{~min}$, absorbance readings were taken at $560 \mathrm{~nm}$ after stirring for $10 \mathrm{~s}$. The negative control consisted of BHIg and bacteria, and the positive control was $10 \mu \mathrm{L}$ of ciclopirox olamine. The concentrations required for biofilm inhibition were assessed by comparing the optical densities of treatment wells to those of control wells. Tests were performed in triplicate.

\section{Supplementary Information}

Supplementary data $\left({ }^{1} \mathrm{H},{ }^{13} \mathrm{C}\right.$ NMR and mass spectra $)$ are available free of charge at http://jbcs.sbq.org.br as PDF file. 


\section{Acknowledgments}

We thank FAPEMIG for the grant awarded to G. D.-M. (APQ-01061-14) and PRPq-UFMG for the scholarship awarded to G. N. S. D.

\section{References}

1. For selected reviews, see: Sridharan, V.; Suryavanshi, P. A.; Menéndez, J. C.; Chem. Rev. 2011, 111, 7157; Nammalwar, B.; Bunce, R. A.; Molecules 2014, 19, 204; Diaz-Muñoz, G.; Dudley, G. B.; Org. Prep. Proced. Int. 2015, 47, 179.

2. Jacquemond-Collet, I.; Hannedouche, S.; Fabre, N.; Fourast, I.; Moulis, C.; Phytochemistry 1999, 51, 1167.

3. Rakotoson, J. H.; Fabre, N.; Jacquemond-Collet, I.; Hannedouche, S.; Fourasté, I.; Moulis, C.; Planta Med. 1998, 64, 762 .

4. Jacquemond-Collet, I.; Benoit-Vical, F.; Valentin, M. A.; Stanislas, E.; Mallie, M.; Fourasté, I.; Planta Med. 2002, 68, 68.

5. Snider, B. B.; Ahn, Y.; O'Hare, S. M.; Org. Lett. 2001, 3, 4217.

6. Davies, S. G.; Fletcher, A. M.; Lee, J. A.; Lorkin, T. J. A.; Roberts, P. M.; Thomson, J. E.; Org. Lett. 2013, 15, 2050.

7. Ferranti, A.; Garuti, L.; Giovanninetti, G.; Gaggi, R.; Roncada, P.; Nardi, P.; Farmaco, Ed. Sci. 1987, 42, 237.

8. Carling, R. W.; Leeson, P. D.; Moseley, A. M.; Smith, J. D.; Saywell, K.; Tricklebank, M. D.; Kemp, J. A.; Marshall, G. R.; Foster, A. C.; Grimwood, S.; Bioorg. Med. Chem. Lett. 1993, 3,65 .

9. Smirnova, T. A.; Gavrilov, M. Y.; Nazmetdinov, F.; Kolla, V. E.; Kon'shin, M. E.; Pharm. Chem. J. 1999, 33, 370.

10. Oshiro, Y.; Sakurai, Y.; Sato, S.; Kurahashi, N.; Tanaka, T.; Kikuchi, T.; Tottori, K.; Uwahodo, Y.; Miwa, T.; Nishi, T.; J. Med. Chem. 2000, 43, 177.

11. Scott, J. D.; Miller, M. W.; Li, S. W.; Lin, S.-I.; Vaccaro, H. A.; Hong, L.; Mullins, D. E.; Guzzi, M.; Weinstein, J.; Hodgson, R. A.; Varty, G. B.; Stampord, A. W.; Chan, T.-Y.; McKittrick, B. A.; Greenlee, W. J.; Priestley, T.; Parker, E. M.; Bioorg. Med. Chem. Lett. 2009, 19, 6018.

12. Moon, M. W.; Morris, J. K.; Heier, R. F.; Chidester, C. G.; Hoffmann, W. E.; Piercey, M. F.; Althaus, J. S.; VonVoigtlander, P. F.; Evans, D. L.; Figur, L. M.; Lahti, R. A.; J. Med. Chem. 1992, 35, 1076.

13. Holsworth, D. D.; Cai, C.; Cheng, X.-M.; Cody, W. L.; Downing, D. M.; Erasga, N.; Lee, C.; Powell, N. A.; Edmunds, J. J.; Stier, M.; Jalaie, M.; Zhang, E.; Bioorg. Med. Chem. Lett. 2006, 16, 2500.

14. Holsworth, D. D.; Jalaie, M.; Belliotti, T.; Cai, C.; Collard, W.; Ferreira, S.; Powell, N. A.; Stier, M.; Zhang, E.; McConnell, P.; Mochalkin, I.; Ryan, M. J.; Bioorg. Med. Chem. Lett. 2007, 17, 3575 .
15. Powell, N. A.; Ciske, F. L.; Cai, C.; Holsworth, D. D.; Mennen, K.; Van Huis, C. A.; Jalaie, M.; Day, J.; Mastronardi, M.; McConnell, P.; Mochalkin, I.; Zhang, E.; Bioorg. Med. Chem. 2007, 15, 5912.

16. Güller, R.; Binggeli, A.; Breu, V.; Bur, D.; Fischli, W.; Hirth, G.; Jenny, C.; Kansy, M.; Montavon, F.; Müller, M.; Oefner, C.; Stadler, H.; Vieira, E.; Wilhelm, M.; Wostl, W.; Märki, H. P.; Bioorg. Med. Chem. Lett. 1999, 9, 1403.

17. Huang, X.; Brubaker, J.; Peterson, S. L.; Butcher, J. W.; Close, J. T.; Martinez, M.; MacCoss, R. N.; Jung, J. O.; Siliphaivanh, P.; Zhang, H.; Aslanian, R. G.; Biju, P. J.; Dong, L.; Huang, Y.; McCormick, K. D.; Palani, A.; Shao, N.; Zhou, W.; WO pat. $2012174176 A 12012$.

18. Gutierrez, M.; Carmona, U.; Vallejos, G.; Astudillo, L.; Z. Naturforsch., C: J. Biosci. 2012, 67, 551.

19. Fonseca-Berzal, C.; Merchan, A. D. R.; Romero, B. A. R.; Escario, J. A.; Kouznetsov, V. V.; Gomez-Barrio, A.; Med. Chem. Lett. 2013, 23, 4851.

20. Wallace, O. B.; WO pat. $2002094788 A 12002$.

21. Kohno, Y.; Kojima, E.; EU pat. EP403980A1 1990.

22. Kohno, Y.; Awano, K.; Ishizaki, T.; Kojima, E.; Kudoh, S.; Sakoe, Y.; Saito, K.; WO pat. $9218482 A 11992$.

23. Feng, L.; Huang, M.; Liu, Y.; Wu, G.; Yan, S.; Yun, H.; Zhou, M.; US pat. 20120190677A1 2012.

24. Avemaria, F.; Vanderheiden, S.; Bräse, S.; Tetrahedron 2003, 59,6785 .

25. Kouznetsov, V. V.; Bohórquez, A. R. R.; Stashenko, E. E.; Tetrahedron Lett. 2007, 48, 8855.

26. Patil, N. T.; Wu, H.; Yamamoto, Y.; J. Org. Chem. 2007, 72, 6577.

27. Shahane, S.; Louafi, F.; Moreau, J.; Hurvois, J.-P.; Renaud, J.-L.; van de Weghe, P.; Roisnel, T.; Eur. J. Org. Chem. 2008, 27, 4622.

28. Diaz-Muñoz, G.; Isidorio, R. G.; Miranda, I. L.; Dias, G. N. S.; Diaz, M. A. N.; Tetrahedron Lett. 2017, 58, 3311.

29. Theeraladanon, C.; Arisawa, M.; Nakagawa, M.; Nishida, A.; Tetrahedron: Asymmetry 2005, 16, 827.

30. Lin, X.-F.; Li, Y.; Ma, D.-W.; Chin. J. Chem. 2004, 22, 932.

31. Wang, W.-B.; Lu, S.-M.; Yang, P.-Y.; Han, X.-W.; Zhou, Y.-G.; J. Am. Chem. Soc. 2003, 125, 10536.

32. Wang, T.-L.; Zhuo, L.-G.; Li, Z.; Chen, F.; Ding, Z.; He, Y.; Fan, Q.-H.; Xiang, J.; Yu, Z.-X.; Chan, A. S. C.; J. Am. Chem. Soc. 2011, 133, 9878.

33. Chen, B.-L.; Wang, B.; Lin, G.-Q.; J. Org. Chem. 2010, 75, 941.

34. Lu, S.-M.; Wang, Y.-Q.; Han, X.-W.; Zhou, Y.-G.; Angew. Chem., Int. Ed. 2006, 45, 2260.

35. Fustero, S.; Moscardó, J.; Jiménez, D.; Pérez-Carrión, M. D.; Sánchez-Roselló, M.; del Pozo, C.; Chem. - Eur. J. 2008, 14, 9868.

36. Hamid, M. H. S. A.; Slatford, P. A.; Williams, J. M. J.; $A d v$. Synth. Catal. 2007, 349, 1555. 
37. Kwon, M. S.; Kim, S.; Park, S.; Bosco, W.; Chidrala, R. K.; Park, J.; J. Org. Chem. 2009, 74, 2877.

38. Liu, X.; Hermange, P.; Ruiz, J.; Astruc, D.; ChemCatChem 2016, 8, 1043.

39. Scheeren, C. W.; Domingos, J. B.; Machado, G.; Dupont, J.; J. Phys. Chem. C 2008, 112, 16463.

40. Diaz-Muñoz, G.; Miranda, I. L.; Sartori, S. K.; Purgato, G. A.; Diaz, M. A. N.; BR pat. 10201801460412018.
41. Clinical and Laboratory Standards Institute (CLSI); Methods for Dilution Antimicrobial Susceptibility Tests for Bacteria that Grow Aerobically, Approved Standard - Seventh Edition, CLSI Document M7-A7; CLSI: Wayne, 2006.

42. Klein, R. C.; Fabres-Klein, M. H.; de Oliveira, L. L.; Feio, R. N.; Malouin, F.; Ribon, A. O. B.; PLoS One 2015, 10, e0120514.

Submitted: May 5, 2018

Published online: July 30, 2018 